\title{
LINGUISTIC CODES OF VOLGOGRAD GODONYMS AS A REFLECTION OF REGIONAL TOPONYMIC POLICY ${ }^{1}$
}

\author{
Dmitriy Yu. Ilyin \\ Volgograd State University, Volgograd, Russia \\ Elena G. Sidorova \\ Volgograd State University, Volgograd, Russia
}

\begin{abstract}
The article analyzes the year-name space of the city of Volgograd (godonyms), interpreted as a set of names of linear geographic objects officially recorded on the territory of a settlement. The linguistic codes most in demand in the regional toponymic policy have been identified and characterized, the most important features of these codes are consistency, structure, repletion with relevant to users information, and in some cases conventionality, symbolism consigning positive semantics. It is argued that the extremely frequent codes for nominating the intracity linear topo objects of Volgograd are memorial, local, anthropogenic and conditionally symbolic ones. It has been established that memoratives can be subdivided into personal, group, and associated with some significant events. Personal memoratives are distributed over the three strata: godonyms commemorating world-famous people, godonyms naming places after iconic personalities in the national community, godonyms based on the names of people recognized in the region. Godonyms, designed to preserve the memory of military exploits committed during the defense of the city in different historical epochs, prevail among group and event memoratives. The most urgent tasks in the field of municipal toponymic policy are outlined as being associated with increase in degrees of name uniqueness within the city, reduction of onyms that contain numerals and abbreviations, and raising requirement to linguistic consistency and accurate spelling of godonyms.

Key words: toponymy, godonym, godonymic space, linguistic code, toponymic policy, name uniqueness, degree of name uniqueness.

Citation. Ilyin D. Yu., Sidorova E.G. Linguistic Codes of Volgograd Godonyms as a Reflection of Regional Toponymic Policy. Vestnik Volgogradskogo gosudarstvennogo universiteta. Seriya 2. Yazykoznanie [Science Journal of Volgograd State University. Linguistics], 2020, vol. 19, no. 6, pp. 69-80. (in Russian). DOI: https:// doi.org/10.15688/jvolsu2.2020.6.6
\end{abstract}

\section{ЛИНГВИСТИЧЕСКИЕ КОДЫ ВОЛГОГРАДСКИХ ГОДОНИМОВ КАК ОТРАЖЕНИЕ РЕГИОНАЛЬНОЙ ТОПОНИМИЧЕСКОЙ ПОЛИТИКИ ${ }^{1}$

\author{
Дмитрий Юрьевич Ильин \\ Волгоградский государственный университет, г. Волгоград, Россия \\ Елена Геннадьевна Сидорова \\ Волгоградский государственный университет, г. Волгоград, Россия
} \\ Аннотация. В статье анализируется годонимическое пространство г. Волгограда, трактуемое как сово- купность названий линейных географических объектов, официально зафиксированных на территории насе- ленного пункта. Определены и охарактеризованы наиболее востребованные в региональной топонимичес- кой политике лингвистические коды, важнейшими признаками которых являются системность, структур-}


ность, наполненность определенной информацией, релевантной для пользователей, и в некоторых случаях условность, символизм, передающий позитивную семантику. Утверждается, что к частотным кодам при номинировании внутригородских линейных топообъектов Волгограда относятся меморативный, локативный, антропогенный и условно-символический. Меморативы делятся на личностные, групповые и событийные. Установлено, что личностные меморативы распределены по трем стратам: годонимы в честь, во-первых, известных в мировом сообществе людей, во-вторых, знаковых в национальном сообществе личностей, в-третьих, известных в данном регионе людей. Среди групповых и событийных меморативов большинство составляют годонимы, призванные сохранить память о воинских подвигах, совершенных при защите города в разные исторические эпохи. Обозначены наиболее актуальные задачи в сфере муниципальной топонимической политики, связанные с повышением степени уникальности названия в пределах города, сокращением нумеративных и аббревиатурных онимов, повышением внимания к соблюдению языковой системности и орфографической правильности годонимов.

Ключевые слова: топонимика, годоним, годонимическое пространство, лингвистический код, топонимическая политика, уникальность названия, степень уникальности названия.

Цитирование. Ильин Д. Ю., Сидорова Е. Г. Лингвистические коды волгоградских годонимов как отражение региональной топонимической политики // Вестник Волгоградского государственного университета. Серия 2, Языкознание. - 2020 - Т. 19, № 6. - C. 69-80. - DOI: https://doi.org/10.15688/jvolsu2.2020.6.6

\section{Постановка проблемы}

В последнее время внимание в ономастических исследованиях акцентируется на изучении структурирования представлений о ландшафтном пространстве территории, которое непосредственным образом влияет на топонимическую политику. Подверженные изменению запросы социума и действия властных структур в части топонимической номинации требуют отклика лингвистов в целях успешного позиционирования городского пространства. В свете сказанного важная систематизирующая роль отводится топонимам, являющимся своеобразными маркерами локуса (см. подробно: [Ильин, Сидорова, 2019; Климкова, 2018; Юдина, Кузнецова, 2018]).

Особое внимание при этом уделяется изучению годонимов, которые интерпретируются как «название линейного объекта в городе, в т.ч. проспекта, улицы, линии, переулка, проезда, бульвара, набережной» [Подольская, 1988 , с. 52]. Значимость указанного разряда проприативной лексики детерминирована отражением в наименованиях линейных топообъектов культурных представлений жителей той или иной местности, их устоев, обычаев и верований, трансформацией ценностных стереотипов и приоритетов социума, информацией о его исторических, идеологических и эстетических вкусах и пристрастиях. Наконец, внимание исследователей к годонимам определяется и тем, что в них находит отражение эволюция современных номинативных техно- логий (см. об этом: [Голомидова, 2019; Ильин, Сидорова, 2014]).

Объектом нашего исследования являются годонимы Волгограда, зафиксированные в «Общегородском перечне наименований элементов улично-дорожной сети и элементов планировочной структуры городского округа город-герой Волгоград» (далее - Перечень), размещенном на официальном сайте администрации г. Волгограда. По состоянию на 10.03.2020 г. (дата последнего внесения изменения в Перечень) в годонимическом пространстве Волгограда, понимаемом нами как совокупность зарегистрированных названий линейных топообъектов, находящихся на территории населенного пункта, насчитывается 2002 улицы, 257 переулков, 22 проезда, 13 площадей, 8 проспектов, 5 набережных, 2 бульвара, 2 шоссе, 2 тупика и 1 разъезд.

Предметом исследования выступают лингвистические коды объектов искусственной номинации - элементов улично-дорожной сети Волгограда.

К настоящему времени код, несмотря на частотное использование в языковедческих работах, получает неясное определение, поскольку в лингвистических словарях и справочниках отсутствует дефиниция этого понятия.

В «Большом академическом словаре русского языка» лексическая единица код определяется как «совокупность условных обозначений (знаков, символов, сигналов и т. п.) и система определенных правил, применяемых для передачи (обработки, хранения) со- 
общений по каналам связи и информации (данных) по каналам телемеханики» (БАС, т. 8, c. 185). Инкорпорируя в предложенное толкование лингвистический смысл, полагаем, что применительно к ономастическим исследованиям лингвистический код можно интерпретировать следующим образом: способы и средства создания лексических единиц с целью номинации объекта внеязыковой действительности в соответствии с системой определенных правил, присущих языку. Важнейшими характеристиками лингвистического кода, на наш взгляд, являются системность, структурность, наполненность определенной информацией, релевантной для пользователей, и в некоторых случаях символизм, условность.

\section{Лингвистические коды названий линейных топообъектов Волгограда}

Годонимическое пространство Волгограда многогранно и разнопланово, поскольку городская структура под воздействием социальных и экономических приоритетов имеет тенденцию к изменению, в том числе с точки зрения количества и качества корпуса именуемых внутригородских объектов. В связи с этим системное описание годонимов даст возможность сформировать целостное представление об особенностях структурно-семантической организации волгоградской годонимии, определить параметры, по которым проходит лингвистическое кодирование линейных городских объектов, выявить характерные тенденции в развитии топонимической политики, показать ее сильные и слабые стороны.

Один из востребованных лингвистических кодов в волгоградской годонимии - меморативный. Характеризуя лингвокультурное пространство областной столицы, можно стратифицировать три разновидности меморативов: личностные, групповые и событийные.

Наиболее широко представлены личностные меморативы; в основе таких номинаций лежит увековечивание памяти:

- участников революционного движения XIX-XX вв., причем улицы носят имена не только известных российских революционеров: улииь Софьи Перовской, Баумана, Володарского, Желябова, но и региональных деятелей: улииа им. Вершинина названа в честь Григория Авдеевича Вершинина, являвшегося руководителем большевиков Краснооктябрьского района г. Царицына, а также представителей международного революционного движения: улица им. Грамши названа в честь основателя коммунистической партии Италии Антонио Грамши;

- участников Гражданской войны: улииьь им. Чапаева, им. Котовского, им. Сергея Лазо, в том числе участников обороны Царицына: улицы им. Воронкова, им. Дундича, им. Булаткина, им. Жлобы - и местных уроженцев: улииа им. Бахтурова названа в честь героя Гражданской войны, родившегося в станице Качалинской;

- участников Великой Отечественной войны: улиць им. Гастелло, им. Черняховского, им. Покрышкина, им. Марины Расковой, в том числе Сталинградской битвы: улищы им. Александра Баскакова, им. Денисенко, им. Глазкова, им. Маршала Толбухина, им. Маршала Чуйкова, им. Сержанта Воронова, и местных уроженцев, отличившихся во время войны: улицы им. Ивана Антонова, им. Саши Филиппова, им. Доченко;

- значимых исторических личностей как в масштабах страны и мира: улицы им. Колумба, им. Клары Цеткин, Кутузовская, им. Степана Разина, им. Гагарина, им. Лейтенанта Шмидта, бульвар им. Энгельса, переулок им. Марата, так и в региональном масштабе: улииа им. Григория Засекина в честь основателя г. Царицына, улииа им. Михайлова в честь первого директора Сталинградского тракторного завода, улииа им. Солнечникова в честь Героя России, ценой своей жизни спасшего солдат во время учений в 2012 году.

Репрезентативным и в годонимическом пространстве Волгограда представляются меморативы, связанные с увековечиванием памяти личностей по профессиональной принадлежности:

ученых: улищы им. Попова, им. Академика Королева, им. Галилея, им. Лобачевского, им. Академика Богомольиа, им. Дарвина, проспект им. Столетова;

- писателей, получивших известность в стране и мире: улищьл им. Аксакова, им. Булгакова, им. Лермонтова, им. Пушкина, им. Чехова, им. Шекспира, им. Анри Барбюса, 


\section{РАЗВИТИЕ И ФУНКЦИОНИРОВАНИЕ РУССКОГО ЯЗЫКА}

им. Гейне, а также местных уроженцев: улииа им. Маргариты Агашиной в честь известной поэтессы, почетного гражданина города-героя Волгограда;

- художников: улищы им. Айвазовского, им. Брюллова, им. Грекова;

- композиторов и музыкантов: улииьы им. Антонина Дворжака, им. Композитора Алябьева, им. Римского-Корсакова;

- спортсменов: улицы им. Поддубного, им. Алехина, им. Чигорина (названа в честь основателя русской шахматной школы);

- скульпторов и архитекторов: переулок им. Алабяна, улица им. Баженова, в том числе значимых для Волгоградской области: улица им. Вучетича;

- актеров и режиссеров: улииь им. Довженко, им. Волкова, в том числе работавших в местных театрах: улица им. Ивана Лапикова.

Анализ языкового материала дает основания утверждать, что личностные меморативы, как правило, распределены по трем стратам: годонимы в честь известных в мировом сообществе людей; знаковых в национальном сообществе личностей; известных в регионе людей.

Групповые меморативы также неоднородны. Во-первых, это годонимы, указывающие на воинские подразделения и иные группы, принимавшие участие в военных событиях: ул. 10-й Дивизии НКВД, ул. 13-й Гвардейской, ул. 62-й Армии, ул. 26 Бакинских Комиссаров, ул. 33-х Героев. Как правило, все наименования линейных топообъектов в данном случае связаны со Сталинградской битвой, стремлением увековечить в памяти наиболее значимое для региона в XX в. историческое событие. Следует отметить, что при наличии улицы 26 Бакинских Комиссаров, получившей название в честь группы героев, расстрелянных интервентами в 1918 г., в Волгограде имеются и улицы, названные в отдельности в честь каждого комиссара: улиизы им. Азизбекова, им. Басина, им. Богданова, им. Габымева, им. Джапаридзе и др.

Во-вторых, это годонимы, которые получили свое наименование в честь людей в составе группы по профессиональной направленности с целью обратить внимание на созидательный труд в мирное время: шоссе Авиаторов, улиць Водников, Домостроителей.
В годонимическом пространстве Волгограда зафиксированы и событийные меморативы. Как правило, это номинации - посвящения различным памятным датам и вехам отечественной истории: улищы 25-летия Октября, 50-летия ВЛКСМ, Обороны Ленинграда, Обороны Одессы, Обороны Севастополя. Большая часть подобных меморативов обращена к событиям Великой Отечественной войны, причем процесс увековечивания исторических событий продолжается и в настоящее время, когда новые топообъекты получают свое наименование: площяадь Сталинградской Победы, улица 70-летия Победы.

Анализ массива фактов позволяет утверждать, что особое место в годонимическом пространстве Волгограда принадлежит лингвистическому коду, который можно интерпретировать как названия с локативной семантикой:

- номинации улиц, образованные от названий государств: улицы Китайская, Венгерская, Словачкая;

- столиц бывших республик СССР, причем, как правило, названия линейных топообъектов охватывают практически все столицы, что было достаточно значимым в советское время для большого города: улищы Ашхабадская, Бакинская, Ереванская;

- субъектов Российской Федерации: улииъы Адыгейская, Башкирская, Бурятская; населенных пунктов других государств: улиць Льежа, Варшавская, Венская, переулки Варненский, Ченстоховский, в том числе носящих имена городов-побратимов Волгограда: улииь Остравская, Порт-Саида, Хиросимы, Ковентри;

- населенных пунктов бывшего СССР и современной России: улицы Великолукская, Псковская, Петербургская, Вешенская.

Отличительной чертой годонимического пространства Волгограда является наличие улиц, названных по наименованиям населенных пунктов Волгоградской области: улицы Абганеровская (рабочий поселок Абганерово), Алексеевская (станица Алексеевская), Бударинская (станция Бударино).

В совокупности годонимических наименований обнаружены номинации городских улиц, получивших название от гидрообъектов: улииы Абаканская, Азовская, Байкальская, в том числе и водных объектов, находящихся 
на территории Волгоградской области: улищь Добринская, Карповская, Сарпинская; оторонимические наименования: переулок Альпийский, улицы Араратская, Эльбрусская; названия от сторон света: улищь Южная, Восточная, переулок Северный.

В языковом массиве обнаружены годонимы, лингвистическим кодом которых служит наименование по антропогенному топообъекту, то есть созданному человеком в целях обустройства жизни, быта: улицы Автомагистральная, Аэродромная, переулки Банный, Больничный, проезд Аптечный, а также номинации, данные в зависимости от особенностей географического положения и ландшафта отдельного линейного топообъекта, его размера и конфигурации: улищь Береговая, Крутоовражная, Малая, Окружная, Пригородная, Кольиевая, Короткая, Крайняя, проезд Крутой, переулки Замкнутый, Долгий.

Следующий лингвистический код, положенный в основу названий волгоградских годонимов, является нумеративным. Таковых наименований насчитывается небольшое количество: проезды 1-ц̌, 2-й, улицы Первая, Пятая.

В годонимическом пространстве Волгограда обнаруживаются наименования, лингвистическим кодом которых следует считать условно-символический, поскольку такие названия вызывают определенные мелиоративные ассоциации: улииы Романтиков, $\mathrm{He}$ жная, Спокойная, Живописная, Дружбы.

Исследование годонимов Волгограда не исчерпывается названными наименованиями, однако в первую очередь возникает вопрос о том, насколько целесообразны названия волгоградских линейных объектов, соответствуют ли они современной топонимической политике.

\section{Проблемы региональной топонимической политики}

Усиление внимания к топонимической политике, рассматриваемой нами в качестве составной части общей языковой политики государства, вполне оправданно. С.Н. Басик, разрабатывая такое научное направление, как критическая топонимика, видит его цель в «кри- тическом осмыслении социально-политической и символической роли топонимов, политики номинации и ее результатов» [Басик, 2018, c. 56].

М.В. Голомидова, подробно анализируя понятие «топонимическая политика», приходит к необходимости трактовки его в статическом и динамическом аспектах: «Рассматриваемая в статическом аспекте, топонимическая политика представляет собой совокупность правовых, организационных, научных, методических, информационно-коммуникационных компонентов, которые обеспечивают регламент присвоения топонимов, а также нормы их употребления в сфере деловой коммуникации. В динамическом аспекте топонимическая политика есть сама практика присвоения официальных топонимов пространственным объектам, которая осуществляется уполномоченными субъектами права» [Голомидова, 2018 , с. 36]. Такая трактовка топонимической политики, по мнению ученого, «позволяет на начальном этапе вывести ее из смыслового поля других “политик” и сосредоточиться на объяснении, которое связано прежде всего с главной функцией топонимов - функцией “адресной”, или, точнее, “координатной”» [Голомидова, 2018, с. 44].

Юридической основой для осуществления системы мероприятий, необходимых при проведении топонимической политики, является Федеральный закон № 152-Ф3 «О наименованиях географических объектов» (в ред. 30.12.2015 г.), который «устанавливает правовые основы деятельности в области присвоения наименований географическим объектам и переименования географических объектов, а также нормализации, употребления, регистрации, учета и сохранения наименований географических объектов как составной части исторического и культурного наследия народов Российской Федерации» (Федеральный закон № 152-Ф3).

Вопросы топонимической политики в рамках того или иного субъекта РФ призваны координировать региональные топонимические комиссии, комитеты по делам территориальных образований и т. п. Перед этими юридически уполномоченными структурами стоит целый ряд непростых задач по упорядочиванию, регистрации и нормализации годонимического 
пространства региона. Безусловно, выполнение указанных задач невозможно без комплексного анализа всего массива географических объектов искусственной номинации, находящихся на территории города. Рассмотрим наиболее важные, по нашему мнению, задачи в сфере топонимической политики Волгограда.

1. Повышение степени уникальности названий в пределах города. Это возможно прежде всего за счет отказа от полностью тождественных наименований линейных топообъектов, что предписывается статьей 7 Федерального закона № 152-Ф3: «Присвоение одного и того же наименования нескольким однородным географическим объектам в пределах административно-территориального образования (административно-территориальной единицы) не допускается» (Федеральный закон № 152-Ф3). С одной стороны, существование множества объектов с одним и тем же названием, обусловленное ментальной и культурноисторической общностью народа, проживающего на определенной территории, составляет, по А.В. Суперанской, ономастическую универсалию [Суперанская, 2007]. К.В. Демьянов и В.Г. Рыженко, анализируя топонимику советского периода, приходят к выводу о том, что «одинаковые названия во всех уголках страны позволяли советскому гражданину ощущать себя частью единой общности» [Демьянов, Рыженко, 2017, с. 159]. Однако, с другой стороны, совпадение наименований двух или более географических объектов в пределах одной административно-территориальной единицы «затрудняет осуществление хозяйственной или иной деятельности» (Федеральный закон № 152-Ф3), в связи с чем закон предусматривает переименование топообъектов, имеющих идентичное название.

Дублирующиеся наименования чрезвычайно частотны в годонимическом пространстве Волгограда: 459 элементов уличнодорожной сети $(19,8 \%$ от общего числа линейных топообъектов) не обладают признаком уникальности на территории города. Наиболее распространены ситуации, когда тождественное название имеют соположенные улицы и переулки, например: улица им. Аверченко и переулок им. Аверченко, улииа Знаменская и переулок Знаменский, улииа им. Ло- моносова и переулок им. Ломоносова, улиияа Мелитопольская и переулок Мелитопольский, улииа Спокойная и переулок Спокойный и др. Если подобное расположение линейных объектов в целом не препятствует выполнению годонимами адресной функции, то в других случаях это затрудняет ее осуществление: переулок Полевой соединяет улииъь Олимпийскую и Гагаринскую, несмотря на наличие в этом же районе города улицы Полевой; улииа им. Войкова расположена в Кировском районе Волгограда, а переулок с аналогичным названием - в Тракторозаводском, улииа Агатовая находится в Красноармейском районе, а переулок Агатовый - в Тракторозаводском, улищы Рубиновая и Удмуртская - в Красноармейском районе, а переулки Рубиновый и Удмуртский - в Советском, улииы Днепровская и Московская в Дзержинском районе, а переулки с аналогичными названиями - в Кировском. Идентичные названия имеют не только улицы и переулки, но и другие элементы улично-дорожной сети, например: площадь им. Дзержинского и улииа им. Дзержинского в Тракторозаводском районе, пломадь им. Куйбышева в Советском районе и улица им. Куйбышева в Красноармейском, проспект Университетский в Советском районе и улица Университетская в Дзержинском, набережная 62-й Армии в Центральном районе и улииа 62-й Армии в Тракторозаводском, площадь им. Белинского в Краснооктябрьском районе и улица им. Белинского в Кировском.

В отдельных случаях одинаковые наименования закрепляются за тремя линейными объектами, например: проспект, площсадь и улица им. В.И. Ленина, улица, переулок и проспект Волжский в разных районах города.

Еще больше затруднений для людей при ориентации в годонимическом пространстве города создают полностью идентичные элементы улично-дорожной сети и их собственные наименования. Так, в Дзержинском районе Волгограда зарегистрированы соположенные улииа Луговая и переулок Луговой, однако улииа Луговая имеется также и на территории Красноармейского района, а переулок Луговой - в Краснооктябрьском районе. Улиия Радужная зафиксирована в Советском и 
Тракторозаводском районах, улица Зенитчиков - в Дзержинском и Тракторозаводском, улииа Крайняя - в Дзержинском и Советском, три улицы в разных районах города имеют наименование Железнодорожная, по четыре улицы носят название Восточная и Садовая.

По-видимому, как дополнительный дифференциальный признак для разграничения одноименных годонимов используются цифровые показатели, например: улииы 1-я Спортивная и 2-я Спортивная, им. Лескова 1-я и им. Лескова 2-я, переулки 1-й Еланский и 2-й Еланский, улииь Капустная балка 1, Капустная балка 2, Капустная балка 3, переулки 1-й Летный, 2-й Летный, 3-й Летныій и 4-й Летный. Абсолютным лидером среди подобных номинаций являются восемь улиц, различающихся только порядковым номером проезда (им. Покровского 1-ци проезд, им. Покровского 2-й проезд, им. Покровского 3-й проезд, им. Покровского 4-й проезд, им. Покровского 5-й проезд, им. Покровского 6-й проезд, им. Покровского 7-й проезд, им. Покровского 8-й проезд), при наличии связывающей их улииы им. Покровского. Однотипные, достаточно громоздкие наименования вряд ли соответствуют коммуникативным потребностям жителей и способствуют выполнению годонимом адресной функции. Наряду с этим зафиксированы наименования с цифровым компонентом, не отражающим реальной топонимической картины. Так, в Красноармейском районе города существует улииа 2-я Динамовская, притом что ни Динамовской, ни 1-й Динамовской нет, в Краснооктябрьском районе есть улииа 4-я Заводская, хотя других улиц с аналогичным наименованием в городе нет, переулки 1-ци Былинный и 3-ци Бblлинный при отсутствии 2-го Былинного, а в Советском районе имеются улицы Ельшанская и 3-я Ельшанская при отсутствии 2-ц̆ Ельшанской.

2. Сокращение нумеративных и аббревиатурных онимов. Статья 7 Федерального закона № 152-Ф3 предусматривает возможность переименования годонима в случаях, когда «географический объект обозначен аббревиатурой, номером или словосочетанием, выполняющими функции наименований географических объектов, но в действительности ими не явля- ющимися» (Федеральный закон № 152-Ф3). Так, на территории Волгограда официально зарегистрированы следующие нумеративные элементы улично-дорожной сети: проезд 1-й, проезд 2-й, улииь Первая, Пятая, Восьмая, Девятая, переулок Восьмой, улица 1050-й км. Кроме того, две улицы города имеют в качестве названия аббревиатуры, не вполне осознаваемые жителями: улица КИМ (Коммунистический интернационал молодежи, существовавший в 1919-1943 гг.) и улища ЛЗС (Лесозащитная станция). Подобные онимы, по нашему мнению, нарушают критерии экологичности (подробнее об этом см.: [Сидорова, $2015 ; 2019])$ и нуждаются в переименовании.

3. Системность онима. Многовековая история образования топонимов позволяет выделять их сложившиеся структурно-семантические типы, в связи с чем требование Федерального закона о том, что название топообъекта должно «естественно вписываться в уже существующую систему наименований географических объектов» (Федеральный закон № 152-Ф3), представляется вполне справедливым. Поскольку годонимы относятся к объектам искусственной номинации, все они являются производными, причем их производящая база, как правило, без труда осознается носителями языка, например: название улицы Медведиикая соотносится с проприативом Медведииа, используемым для номинации реки, протекающей на территории Волгоградской области, Рижская - с проприативом $P и г a$, номинирующим город в Латвии, Транспортная - с апеллятивом транспорт, Штурманская - с апеллятивом штурман и т. п. Итогда производящая база для жителей региона бывает не очевидна: например, название улиц Вельботная от вельбот - «быстроходная весельная или парусная шлюпка с острым носом и кормой» (БАС, т. 2, с. 401), Мопровская от МОПР - Международная организация помощи борцам революции, Oйротская от Ойрот-Тура - прежнего названия г. Горно-Алтайска, использовавшегося в 1932-1948 гг, а в отдельных случаях ее и вовсе невозможно установить: улиць Каральская, Нарезенская.

Системность годонимов как класса топонимической лексики должна проявляться и в соблюдении в них грамматических норм. 
Если наименование переулка Портовый, соотносимое с существительным порт, не вызывает сомнений в выборе словообразовательных средств, то наименование улицы Новопортная с этой точки зрения представляется не вполне корректным (ср.: годонимы Нововокзальная, Новоремесленная, Новошахтинская).

Значительную часть годонимического пространства Волгограда составляют личностные меморативы в форме родительного падежа (им. Атласова, им. Милиционера Буханцева, им. Расула Гамзатова и т. п.), а значит, в некоторых случаях возникают проблемы, связанные со склоняемостью / несклоняемостью конкретной фамилии, закрепленной в названии топообъекта. Совершенно очевидно, что требования грамматических норм одинаково применимы ко всем пластам лексики, в том числе и к антропонимам и топонимам. Так, в соответствии с действующими правилами «иностранные фамилии, оканчивающиеся на гласный звук (кроме неударяемых - $a,-я)$, не склоняются, например: романы Золя, стихотворения Гюго, оперы Бизе, музыка Пуччини, пьесы Шоу» [Розенталь, 1996, с. 205], поэтому подобные фамилии в составе годонимов Волгограда также не склоняются: улииы им. Абрамитвили, им. Гастелло, им. Гейне, им. Сакко и Ванцетти, им. Семашко. Иное правило касается русских и иноязычных фамилий, оканчивающихся на согласный: они «склоняются, если относятся к мужчинам, и не склоняются, если относятся к женщинам» [Розенталь, 1996, с. 205]. В подавляющем большинстве случаев данная рекомендация последовательно реализуется, ср.: улицы им. Стрельияа (Стрелец Николай Григорьевич), им. Бабича (Бабич Олег Иванович), им. Полковника Батюка (Батюк Николай Филиппович), им. Академика Богомольия (Богомолец Александр Александрович), им. Вучетича (Вучетич Евгений Викторович), им. Гоголя (Гоголь Николай Васильевич), им. Дарвина (Дарвин Чарлз Роберт), им. Антонина Дворжака (Дворжак Антонин), им. Тула$к а$ (Тулак Иван Васильевич), им. Дундича (Дундич Томо). Но: переулок им. Розы Люксембург, улицы им. Ольги Фори, им. Клары Цеткин. Между тем нами зафиксирован единичный случай нарушения грамматического норматива - улица им. Командира Рудь (Рудь Дмитрий Филиппович), который требует корректировки в части соответствия грамматической норме.

Еще одной «зыбкой зоной» в годонимическом пространстве Волгограда можно считать наименования, включающие в свой состав географические термины, применимые к другим группам топонимов, например: улииа Река Пионерка, улица Поселок Стройдеталь, а также смешение родо-видовых отношений при употреблении географических терминов (две улицы Набережная, переулки Набережный и 1-й Набережный, пять набережных - 62-й Армии, Волжсской Флотилии, им. Владимира Высоикого, Ельшанская, Севастопольская). Таким образом создается ситуация, при которой в процессе коммуникации может возникать проблема, связанная с осознанием того, в каком значении употребляется лексема набережная - как географический термин, обозначающий «береговую полосу или ее часть (вдоль реки, водоема), укрепленную бетоном, камнем, идущую вдоль населенного места» (РСС, с. 19), либо как собственное наименование улицы или переулка.

4. Оптимальное количество компонентов в составе онима. В соответствии с анализируемым законом наименование географического объекта должно «состоять не более чем из трех слов» (Федеральный закон № 152-Ф3). В годонимическом пространстве Волгограда имеется единичный случай, когда название включает в свой состав большее количество компонентов, - проспект им. Маршала Советского Союза Г.К. Жукова. Неудобство в практическом использовании такого развернутого наименования, в том числе при заполнении адресной строки в различных документах, очевидно. На наш взгляд, более оптимальной будет являться двукомпонентная модель, закрепленная, например, за следующими элементами улично-дорожной сети: улииа им. Композитора Алябьева, переулок им. Генерала Апанасенко, улица им. Лейтенанта Лукина, улииа им. Адмирала Макарова и др. По-видимому, стремлением сократить количество компонентов в структуре годонима объясняется существование таких улиц, как 7-й Гвардейской, 13-й Гвардейской, 35-й Гвар- 
дейской, 36-й Гвардейской, 39-й Гвардейской, 51-й Гвардейской, 95-й Гвардейской. Они получили свои названия в честь конкретных воинских подразделений (7-я гвардейская мотострелковая бригада, 13-я, 35-я, 36-я, 39-я, 51-я, 95-я гвардейские стрелковые дивизии), защищавших Сталинград в 1942-1943 гг., однако при этом произошло выпадение грамматически стержневого компонента из словосочетания, именующего то или иное подразделение. Полагаем, что более корректными были бы названия 7-й Гвардейской Бригады, 13-й Гвардейской Дивизии и т. п., тем более что годонимы такого типа, указывающие на вид воинского подразделения, на территории Волгограда имеются: улищы 64-й $\mathrm{Ap}$ мии, 8-й Воздушной Армии, 10-й Дивизии НКВД.

5. Одним из наиболее очевидных направлений работы уполномоченных органов в сфере топонимической политики является нормирование наименований географических объектов с точки зрения действующих правил орфографии (см., например: [Арутюнова, Бешенкова, Иванова, 2020; Судаков, 2019]). Законом предусматривается внесение изменений в номинацию топонима, если «существующее написание наименования географического объекта на государственном языке Российской Федерации или на других языках народов Российской Федерации не соответствует правилам русской орфографии или орфографии других языков народов Российской Федерации и традициям употребления наименований географических объектов на указанных языках» (Федеральный закон № 152-Ф3). Анализ массива географических наименований объектов искусственной номинации показывает имеющиеся противоречия в орфографическом оформлении годонимов, особенно в части слитно-дефисных написаний и употребления прописных букв в составе неоднокомпонентных имен собственных, например: ГорноАлтайская - Горнополянская, СевероКрымская - Северокавказская, ЮжноСибирская - Южноуральская, 33-х Героев - 4-х связистов, Павших Бориов - Первой конной армии, Малая Садовая - Малая кольиевая. Иногда имеет место орфографически непоследовательное обозначение гласного после шипящих, например: Алычевая, Пе- черская (в Дзержинском районе) - Печорская (в Советском районе).

6. Номинирование вновь образуемых географических объектов с учетом годонимического пространства города и перспектив его дальнейшего развития. Разделяем точку зрения Т.А. Прудниковой по поводу того, что «преобразования, включающие в себя введение новой топонимики, можно считать частью культурной политики государства, направленной на формирование у жителей целостного образа новой... среды, встроенной в контекст определенных ценностей» [Прудникова, 2012, с. 139], что будет способствовать сохранению национальнокультурной идентичности жителей.

\section{Заключение}

Изучение и систематизация годонимического пространства Волгограда позволили представить структурно-семантическую характеристику названий линейных топообъектов города, охарактеризовать частотные лингвистические коды, используемые при обозначении объектов искусственной номинации: меморативный, локативный, антропогенный, нумеративный, условно-символический. Выделены наиболее актуальные задачи в сфере топонимической политики столицы региона: повышение степени уникальности названия в пределах города, сокращение нумеративных и аббревиатурных онимов, внимание к соблюдению языковой системности проприатива, нормирование наименований географических объектов с точки зрения действующих правил орфографии.

\section{ПРИМЕЧАНИЕ}

${ }^{1}$ Исследование выполнено при финансовой поддержке РФФИ в рамках научного проекта № 20-012-00217 «Лингвистические коды объектов искусственной номинации в топонимической политике региона: проблемы, противоречия и векторы развития».

The study was supported by the Russian Foundation for Basic Research (project no. 20-012-00217 "Linguistic codes of objects of artificial nomination in the toponymic policy of the region: problems, contradictions and vectors of development"). 


\section{СПИСОК ЛИТЕРАТУРЫ}

Арутюнова Е. В., Бешенкова Е. В., Иванова О. Е., 2020. Прописные и строчные буквы в географических административно-территориальных названиях: академические правила русской орфографии // Вопросы ономастики. Т. 17, № 2. C. 256-277. DOI: http://10.15826/ vopr onom.2020.17.2.027.

Басик С. Н., 2018. Критическая топонимика как направление географических исследований: проблемы и перспективы // Географический вестник $=$ Geographical bulletin. № 1 (44). C. 56-63. DOI: http://dx.doi.org/10.17072/2079-7877-2018-156-63.

Голомидова М. В., 2018. Топонимическая политика в сфере номинации внутригородских объектов: теоретические и прикладные проблемы // Вопросы ономастики. Т. 15, № 3. С. 36-57. DOI: http://dx.doi.org/10.15826/vopr_onom/ 2018/15/3/028.

Голомидова М. В., 2019. Использование технологий нейминга при создании официальных городских топонимов: анализ возможностей // Вопросы ономастики. Т. 16, № 3. С. 162-178. DOI: 10.15826/vopr_onom.2019.16.3.037.

Демьянов К. В., Рыженко В. Г., 2017. Идеология, топонимика, политика памяти: о массовом переименовании городов в СССР // Вестник Омского университета. Серия «Исторические науки». № 4 (16). С. 153-160. DOI: http://dx.doi.org/ 10.25513/2312-1300.2017.4.153-160.

Ильин Д. Ю., Сидорова Е. Г., 2014. Теоретические основы построения словаря-справочника региональной топонимики // Вестник Волгоградского государственного университета. Серия 2, Языкознание. № 3 (22). С. 7-16. DOI: http://dx.doi.org/10.15688/jvolsu2.2014.3.1.

Ильин Д. Ю., Сидорова Е. Г., 2019. Населенные пункты Волгоградской области: словарь-справочник регионального топонимикона. Волгоград : Изд-во ВолГУ. $411 \mathrm{c.}$

Климкова Л. А., 2018. Российская топонимика и ее объект в аспекте динамики // Ученые записки УО «ВГУ им. П. Н. Машерова». Т. 25. С. 108-115.

Подольская Н. В., 1988. Словарь русской ономастической терминологии. 2-е изд., перераб. и доп. М. : Наука. 192 с.

Прудникова Т. А., 2012. Топонимическая политика Советского государства в контексте культуры сталинского времени (на примере переименования Московского проспекта в Ленинграде в 1950-е годы) // Вестник Санкт-Петербургского университета. Серия 6, Философия. Культурология. Политология. Право. Международные отношения. Вып. 3. С. 139-143.
Розенталь Д. Э., 1996. Справочник по правописанию и литературной правке. М. : Рольф. 368 с.

Сидорова Е. Г., 2015. Лингвоэкологические проблемы топонимического пространства региона // Экология языка и коммуникативная практика. № 2 (5). С.157-166.

Сидорова Е. Г., 2019. Проблема степени уникальности названия поселения в лингвоэкологическом аспекте // Экология языка и коммуникативная практика. № 2 (17). C. 35-42. DOI: http:/ /dx.doi.org/10.17516/2311-3499-056.

Судаков Г. В., 2019. Проблемы употребления названий населенных пунктов (на примере ойконимии Вологодской области) // Вопросы ономастики. Т.16, № 3. С. 193-204. DOI: 10.15826/ vopr_onom.2019.16.3.039.

Суперанская А. В., 2007. Общая теория имени собственного. М. : Изд-во ЛКИ. 368 с.

Юдина Н. В., Кузнецова Е. А., 2018. Топонимический портрет Владимирского края. Владимир : Транзит-ИКС. 160 с.

\section{ИСТОЧНИКИ И СЛОВАРИ}

$Б A C$ - Большой академический словарь русского языка / гл. ред. К. С. Горбачевич. М. ; СПб. : Наука, 2004- Т. 2. 2005. 662 с. ; Т. 8. 2007. $840 \mathrm{c.}$

$P C C$ - Русский семантический словарь. Толковый словарь, систематизированный по классам слов и значений / под общ. ред. Н. Ю. Шведовой. М. : Азбуковник, 1998- . Т. 2. 1998. XXIII, $800 \mathrm{c}$.

Федеральный закон № 152-Ф3 - Федеральный закон от 18.12.1997 № 152-Ф3 (ред. от 30.12.2015) «О наименованиях географических объектов». URL: https://www.zakonrf.info/doc15205113/ (дата обращения: 28.06.2020).

\section{REFERENCES}

Arutyunova E.V., Beshenkova E.V., Ivanova O.E., 2020. Propisnye i strochnye bukvy v geograficheskikh administrativno-territorialnykh nazvaniyakh: akademicheskie pravila russkoy orfografii [Uppercase and Lowercase Letters in Geographical and Administrative Territorial Names: Academic Rules of Russian Spelling]. Voprosy onomastiki [Problems of Onomastics], vol. 17, no. 2, pp. 256-277. DOI: http://10.15826/ vopr_onom.2020.17.2.027.

Basik S.N., 2018. Kriticheskaya toponimika kak napravlenie geograficheskikh issledovaniy: problemy i perspektivy [Critical Toponymics as a 
Direction of Geographic Research: Problems and Perspectivies]. Geograficheskiy vestnik [Geographical bulletin], no. 1 (44), pp. 56-63. DOI: http://dx.doi.org/10.17072/2079-7877-2018-1-56-63.

Golomidova M.V., 2018. Toponimicheskaya politika v sfere nominatsii vnutrigorodskikh ob"ektov: teoreticheskie i prikladnye problemy [Toponymic Policy in Naming City Facilities: Theoretical and Applied Issues]. Voprosy onomastiki [Problems of Onomastics], vol. 15, no. 3, pp. 36-57. DOI: http://dx.doi.org/10.15826/ vopr_onom/2018/15/3/028.

Golomidova M.V., 2019 Ispolzovanie tekhnologiy neyminga pri sozdanii ofitsialnykh gorodskikh toponimov: analiz vozmozhnostey [Use of Product-Naming Techniques for Creating Official City Toponyms: Analysis of Perspectives]. Voprosy onomastiki [Problems of Onomastics], vol. 16, no. 3, pp. 162-178. DOI: $10.15826 /$ vopr onom.2019.16.3.037.

Demyanov K.V., Ryzhenko V.G., 2017. Ideologiya, toponimika, politika pamyati: o massovom pereimenovanii gorodov v SSSR [Ideology, Toponymy, Policy of Memory: about City's Renaming in the USSR]. Vestnik Omskogo universiteta. Seriya Istoricheskie nauki [Herald of Omsk University. Series Historical Studies], no. 4 (16), pp. 153-160. DOI: http://dx.doi.org/ 10.25513/2312-1300.2017.4.153-160.

Ilyin D.Yu., Sidorova E.G., 2014. Teoreticheskie osnovy postroeniya slovarya-spravochnika regionalnoy toponimiki [Theoretical Foundations of Composing a Reference Book of Regional Toponyms]. Vestnik Volgogradskogo gosudarstvennogo universiteta. Seriya 2, Yazykoznanie [Science Journal of Volgograd State University. Linguistics], no. 3 (22), pp. 7-16. DOI: http://dx.doi.org/10.15688/jvolsu2.2014.3.1.

Ilyin D.Yu., Sidorova E.G., 2019. Naselennye punkty Volgogradskoy oblasti: slovar-spravochnik regionalnogo toponimikona [Settlements of the Volgograd Region: Dictionary Directory of Regional Toponymy]. Volgograd, Izdatelstvo VolGU. 411 p.

Klimkova L.A., 2018. Rossiyskaya toponimika i ee ob"ekt v aspekte dinamiki [Russian Toponymy and its Object in the Aspect of Dynamics]. Uchenye zapiski UO VGU im. P. N. Masherova, vol. 25, pp. 108-115.

Podolskaya N.V., 1988. Slovar russkoy onomasticheskoy terminologii [Dictionary of Russian Onomastic Terminology]. $2^{\text {nd }}$ edition. Moscow, Nauka Publ. 192 p.

Prudnikova T.A., 2012. Toponimicheskaya politika Sovetskogo gosudarstva v kontekste kultury stalinskogo vremeni (na primere pereimenovaniya
Moskovskogo prospekta v Leningrade v 1950-e gody) [The toponymic policy of the Soviet state as an urbanistic factor (based on an example of renaming Moskovsky avenue in Leningrad in the 1950 s]. Vestnik Sankt-Peterburgskogo universiteta. Seriya 6. Filosofiya. Kulturologiya. Politologiya. Pravo. Mezhdunarodnye otnosheniya. [Vestnik of Saint Petersburg University. Philosophy. Cultural studies. Political science. Law. International Relations], vol. 3, pp. 139-143.

Rozental D.E., 1996. Spravochnik po pravopisaniyu $i$ literaturnoy pravke [Spelling and literary proofreading reference]. Moscow, Rolf Publ. $368 \mathrm{p}$.

Sidorova E.G., 2015. Lingvoekologicheskie problemy toponimicheskogo prostranstva regiona [Lingvaecological Problems of Toponimic Spase of a Region]. Ekologiya yazyka i kommunikativnaya praktika [Ecology of Language and Communicative Practice], no. 2 (5), pp. 157-166.

Sidorova E.G., 2019. Problema stepeni unikalnosti nazvaniya poseleniya $\mathrm{v}$ lingvoekologicheskom aspekte [The Problem of the Degree of Uniqeness of the Name of the Settlement in the Lingvoecological Aspect]. Ekologiya yazyka $i$ kommunikativnaya praktika [Ecology of Language and Communicative Practice], no. 2(17), pp. 35-42. DOI: http://dx.doi.org/10.17516/23113499-056.

Sudakov G.V., 2019. Problemy upotrebleniya nazvaniy naselennykh punktov (na primere oykonimii Vologodskoy oblasti) [Settlement Names: Problems ofConventional Usage (with Reference to Oikonyms of the Vologda Region)]. Voprosy onomastiki [Problems ofOnomastics], vol. 16, no. 3,pp. 193-204. DOI: 10.15826/vopr onom.2019.16.3.039

Superanskaya A.V., 2007. Obshchaya teoriya imeni sobstvennogo [General theory of proper names]. Moscow, Izdatelstvo LKI. 368 p.

Yudina N.V., Kuznetsova E.A., 2018. Toponimicheskiy portret Vladimirskogo kraya [Toponymic portrait of the Vladimir region]. Vladimir, TranzitIKS Publ. 160 p.

\section{SOURCES AND DICTIONARIES}

Bolshoy akademicheskiy slovar russkogo yazyka [The Comprehensive Academic Dictionary of the Russian Language]. K.S. Gorbachevich (ed.). Vol. 2. Moscow, Saint Petersburg, Nauka Publ., 2005. 662 p.; Vol. 8. Moscow, Saint Petersburg, Nauka Publ., 2007. 840 p.

Russkiy semanticheskiy slovar. Tolkovyy slovar, sistematizirovannyy po klassam slov i znacheniy 


\section{РАЗВИТИЕ И ФУНКЦИОНИРОВАНИЕ РУССКОГО ЯЗЫКА}

[Russian semantic dictionary]. N.Yu. Shvedova (ed.). Vol. II. Moscow, Azbukovnik, 1998. XXIII, 800 p. Federalnyy zakon № $152-\mathrm{FZ}$ «O naimenovaniyakh geograficheskikh ob"ektov» (v red. 30.12.2015)
[Federal Law No. 152-FZ "On Names of Geographical Objects" (as amended on 30.12.2015)]. URL: https://www.zakonrf.info/ doc-15205113 (accessed 28 June 2020).

\section{Information About the Authors}

Dmitriy Yu. Ilyin, Doctor of Sciences (Philology), Associate Professor, Vice-Rector for Academic Affairs, Volgograd State University, Prosp. Universitetsky, 100, 400062 Volgograd, Russia, dilyin@volsu.ru, https://orcid.org/0000-0001-6387-757X

Elena G. Sidorova, Candidate of Sciences (Philology), Associate Professor, Department of Russian Philology and Journalism, Volgograd State University, Prosp. Universitetsky, 100, 400062 Volgograd, Russia, eg_sidorova@volsu.ru, https://orcid.org/0000-0002-7705-1311

\section{Информация об авторах}

Дмитрий Юрьевич Ильин, доктор филологических наук, доцент, проректор по учебной работе, Волгоградский государственный университет, просп. Университетский, 100, 400062 г. Волгоград, Россия, dilyin@volsu.ru, https://orcid.org/0000-0001-6387-757X

Елена Геннадьевна Сидорова, кандидат филологических наук, доцент кафедры русской филологии и журналистики, Волгоградский государственный университет, просп. Университетский, 100, 400062 г. Волгоград, Россия, eg_sidorova@volsu.ru, https://orcid.org/0000-0002-7705-1311 